\title{
The Impacts of Trade Protectionism on the Indian Economy
}

\author{
Xi Cheng ${ }^{1, *}{ }^{*}$, Xinyue $\mathrm{Fu}^{2, \dagger}$, Yuntian Tang ${ }^{3, \dagger}$, Zuqian Wang ${ }^{4, \dagger}$ \\ ${ }^{1} H K U$ Business School, University of Hong Kong, Hongkong, 999077, China \\ ${ }^{2}$ Jinan Foreign Language School, Jinan, 250100, China \\ ${ }^{3}$ School of Economics, Zhejiang University, Hangzhou, 310058, China \\ ${ }^{4}$ School of English Studies, Dalian University of Foreign Languages, Dalian, 116000, China \\ *Corresponding author.Email: u3594197@connect.hku.hk \\ ${ }^{\top}$ Those authors contributed equally.
}

\begin{abstract}
Since the 1970s, many countries have brought many benefits to their own countries due to the development of globalization. But some typical countries, such as India, began to show some anti-globalization phenomena. So, they put in place relevant policies to protect their national interests. Because of this situation, the theme of our study will focus on how protectionism impacts India. This paper will use quantitative analysis with the ordinary least squares regression model to research the impacts of tariffs on the economy of India. The regression models indicate a positive correlation between tariff and GDP while a weak relationship between GDP and joining a new regional trade agreement. To sum up, this paper indicates that although reducing tariff level to some extent is beneficial for the economic development in India; the country should adopt a variety of protectionism methods appropriately. In addition, with the increasingly developed pharmaceutical industries, the Indian government may open its market again gradually with fewer protectionism policies. And this result focuses not only on several industries but also on the country's economy. Contribution and limitation will be further discussed in this paper.
\end{abstract}

Keywords: Trade protectionism, India, OLS regression model.

\section{INTRODUCTION}

Beginning in the 1970s, the concept of globalization slowly began to take hold. In recent decades, globalization has become increasingly popular. Mussa in 2003 showed that globalization might be defined as the increasing interaction among and integration of the activities, especially economic activities, of human societies around the world [1]. There are oceans of research indicating many benefits of free trade, including reducing the unemployment rate, enabling firms to specialize, reducing high inflation rates, etc. However, there are also some arguments against globalization. Excessive globalization can also be deleterious for some countries. For example, there are many jobs in India necessary for people's lives because of its large population. Market share grasped by international companies raises with the increase in globalization. If one country imports a significantly large amount of homogeneous goods at a price lower than the domestic price, domestic jobs will drop due to decreased demand for domestically-produced commodities, leading to an increase in the natural unemployment rate. Thus, the promotion of free trade can impose a threat to the employment rate of India. This phenomenon is unfavorable for the development of the Indians. The Indian government has implemented various measures to place high trade barriers since India became independent in 1947 like high average tariff and import licensing. Under the trend of globalization, despite the continual decline in trade barriers of India since the 1990s, the Indian government selected several items that must be certified by the Bureau of Indian Standards (BIS) and the National Bureau of Standards. Moreover, India regularly imposes anti-dumping and countervailing rules to protect domestic manufacturers from dumping, which is adopted by World Trade Organization (WTO) agreement to protect domestic industries from serious injury caused by dumping or subsidized imports.

Protectionism will greatly reduce imports, providing a less competitive market for domestic firms. India's trade protectionism seems to be beneficial for the 
domestic industries, especially emerging industries. Protectionism provides a relatively stable environment for the growth of the domestic industry. This is particularly important for some industries that are still in their infancy and immature stage. And through supporting domestic firms, protectionism aims to encourage export as a result. Figure 1 displays that India's increase in total exports has grown faster than imports since 1990, indicating the rapid development of domestic industries. By ensuring the stable development of domestic industries, policymakers expect domestic industries to be strong enough so that high trade barriers would be unnecessary one day. However, although the Indian government has reduced its average tariff to a great extent in recent years, Indian trade barriers still tend to be at a high level worldwide. According to the World Bank collection of development indicators, the tariff rate, applied, simple mean, all products in the world were reported at $5.17 \%$ in 2017 . However, according to the WTO data of 2017 available, India's average bound tariff rate is 48.5 percent, while its simple MFN average applied tariff is 13.8 percent [2].

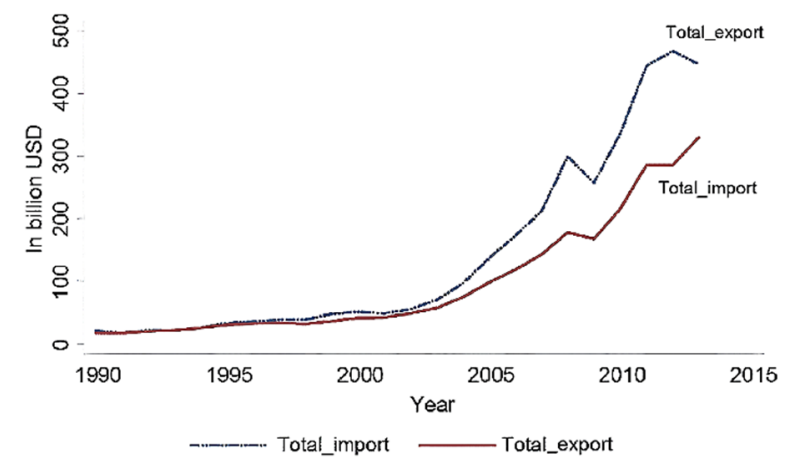

Figure 1. Total Exports \& Imports of India [3]

Despite the global trend of free trade, it is observed that protectionism persists worldwide, as India mentioned above. Thus, this paper decides to research the effects of protectionism to find why protectionism still acts as one essential of policy principles. In this paper, India serves as the targeted objective because few countries currently set high trade barriers. Besides, under India's protectionism, its domestic economy shows a relatively high growth rate. Thus, it is worthy for us to evaluate to which extent protectionism contributes to the development of the Indian economy.

After a review of previous researches, this paper finds that most researchers prefer to study free trade rather than trade protectionism. Furthermore, many researchers prefer to study the economic impacts of free trade on a country or how a country's policies will change under the trend of free trade. For example, Rodriguez and Rodrik study the effects of lower tariff and non-tariff trade barriers and trade policies on economic growth and their relationship through data Analysis [4]. Additionally, the majority of studies acquire the conclusion that governments should support free trade by eliminating trade barriers. Moreover, many previous studies focus on the effects of protectionism on international trade or one aspect of domestic impact, like employment. There are not many researches comprehensively evaluating the impacts on the domestic firms of India. Thus, this paper chooses to conduct in-depth research, covering both demerits and merits of protectionism for the domestic industry of India.

\section{LITERATURE REVIEW}

A large and growing body of literature has investigated both pros and cons of trade protectionism. This paper will focus on how trade protectionism has influenced the economic development in India.

\subsection{The Definition of Protectionism}

Some previous studies reveal great benefits brought by trade protectionism. In 2010, Abboushi and Suhail demonstrated that protectionism is the sum of government trade policies intended to assist domestic producers against foreign producers in a particular industry by raising the price of foreign products, lowering domestic producers' costs, and limiting imports producers' access to domestic market [5].

\subsection{Merits and Demerits of Protectionism}

Whether protectionism is good or bad for the development of an economy is a matter of long dispute, and scholars worldwide have demonstrated various views. Cambazoğlu and Birgül in 2020 showed that these views are divided into two opposite camps. The first camp focuses on the benefits of free international trade to the parties, especially its contribution to economic growth and technological progress. In contrast, the second focuses on the idea that domestic industries, laborers, and cultures are damaged by foreign competition [6]. Abboushi and Suhail, 2010 published a paper and reported that the arguments for protectionism include national defense, trade deficit, employment, infant industries, and fair trade. Specifically, protecting producers in industries such as weapon manufacturing is deemed prudent to protect the country's preparedness for times of adversity. In addition, advocates of protectionism are alarmed at the deficit in the balance of payments current account. Meanwhile, protections reduce imports and preserve some jobs. And at the same time, the newly established industry applies pressure on its government to shield it from the international competition using imposing trade restrictions in the face of imports for many years until the domestic industry presumably establishes its comparative advantage [7].

Opponents, however, argue that protectionism will bring more disadvantages. Baldwin and other researchers in 1988 concluded that protection is not an effective way 
to stimulate domestic output because the reactions of users tend to offset the actions of producers [8]. In addition, Kaempfer and Willett, in 1987, studied the issue of using import surcharge to reduce the trade deficit and concluded that the policy would distort resource allocations and fail to reduce the deficit [9]. McGee and Robert, in 1996, showed that another factor that is often overlooked is the disparate impact that protectionism has on subgroups [10]. Hickok and Susan in 1985 demonstrated that trade restrictions on automobiles, clothing, and sugar cost American consumers \$14 billion in 1984, which amounted to a $23 \%$ income tax surcharge for families that had less than $\$ 10,000$ in income but amounted to only $3 \%$ for families with incomes of over $\$ 60,000$ [11]. McGee and Robert, in 1996, also showed that protectionism destroys more jobs than it creates, so there is the employment cost. Jobs that will be destroyed or the jobs that will never be created result from some protectionist policy [12]. In 1987, Baughman and others found that a particular protectionist policy would save 36,000 apparel manufacturing jobs but cause 58,000 apparel retailing jobs to be lost, for a loss/gain ratio of more than 1.6 to 1 [13]. Luttrell in 1978 demonstrated that employment gains from reduced imports and losses from reduced exports balance each other out with a net employment effect near zero [14]. In addition, McGee and Robert in 1996 demonstrated that protectionism has a social harmony cost. It is a version of class conflict, but rather than pitting the proletariat against the bourgeoisie. It is a conflict between producers versus consumers [15]. Together, these studies outline that protectionism has pros and cons, and most scholars have a resistant attitude to adopting protectionism policies. However, this paper will discuss with such a large number of disadvantages why the Indian government still adopted protectionism policies to boost some infant and pill industries' economic development. And this paper will take the Indian pharmaceutical industry as an example.

\subsection{Pharmaceutical Industry in India}

The pharmaceutical industry is one of the most wellknown industries in India, as there is a significantly large quantity of generic medicines. The whole pharmaceutical industry is quite developed for now, but this was not the case before 1970 . We will take this industry as a case to deepen our understanding of the necessity of protectionism in some specific cases.

In order to figure out the whole development process of the industry, this paper pays closer attention to these three time periods. Before 1970, from 1970-1995, and from 1995 to 2005 , India started to follow more rules made by WTO.

Firstly, before 1970, the Indian government enacted an act called Patent and Design Law, 1911, which recognized both patent of the drug production process and the product patent of the medicine itself. The consequence is that multinational dominated India's pharma market with an $85 \%$ share [16]. This monopoly also gave multinational pharmaceutical companies absolute pricing power, which kept drug prices were constantly high in India.

But things will change when the Gandhi government published another regulation to reverse the trend of relying heavily on multinational companies. The new patents act has two biggest adjustments. One is that patents are not granted on the medicine itself, but only on the methods used to make them, and the law also reduces the duration of patents. Meanwhile, since 1970, the Indian government also published another act (DPCO) to control high drug prices. This act successfully changed the situation of monopoly by multinational companies. Therefore, the series of measures has enabled India's domestic pharmaceutical industry to grow at a dazzling speed, and this paper will use quantitative analysis to understand the development process further. Without protectionism, the industry is not likely to achieve success since it might not compete with foreign companies.

However, almost everything has a turning point, and the establishment of WTO in 1995 could be regarded as a turning point for the pharmaceutical industry in India. Although WTO has given India ten years to adapt, things will change in 2005 as WTO forced India to follow the rules of the Trade-Related Intellectual Property System (TRIPS) agreement. This is not an easy step, which means a more open market, and less protective policies. Without trade barriers, countries with insufficient discourse rights, like India, will face challenges like less competitive domestic products and difficulties to satisfy basic medical needs for poor people due to higher costs under the patent tule. But the Indian Patents Act has already been modified to bring it closer to TRIPS, and we will also provide quantitative analysis to see the following situation.

\section{METHODOLOGY}

\subsection{Modeling \& Data Collection}

This research aims to research the impact of trade barriers on the economy of India using a quantitative method. Since the OLS regression model can serve as a means to evaluate the strength of the relationships between these variables, this paper utilizes it to examine the impact of the average tariff on GDP growth to investigate macroeconomic response. The econometric model is presented in explicit form as:

$$
\mathrm{Y}_{\mathrm{it}}=\beta_{0}+\beta_{1} \operatorname{Ln} \mathrm{T}_{\mathrm{t}}+\beta 2 \mathrm{G}_{\mathrm{t}}+\beta 3 \mathrm{LnEC}_{\mathrm{t}}+\beta 4 \mathrm{Ln} \mathrm{E}_{\mathrm{t}}+\mathrm{e}_{\mathrm{t}}
$$

\section{Where:}


Y: GDP (The total value of all the goods and services produced by a country in one year)

T: Average tariff (HS sub-heading average method)

G: Whether India joined in a new Regional Trade Agreement or not (Dummy variable)

\section{EC: Energy consumption per capita \\ E: Quantity of employment}

The study engages data annual data from 1996 to 2019. The data of GDP and quantity of employment in India come from the CEIC database [17]. Data of energy consumption per capita $(\mathrm{kWh})$ and the population is retrieved from The World Bank. [18] Tariff Download Facility Database of WTO provides the data of average tariff of pharmaceutical products imposed by the Indian government [19]. This research utilizes EViews to adopt regression analysis.

\section{RESULTS}

\subsection{Regression Procedure}

The estimation results for the tariff's impact on India's economy are shown in Table 1 . The reliability of the estimations was tested using the probability value. With a significance level of $1 \%$, a p-value less than 0.01 indicates the best linear unbiased estimates.

Table 1 provides the result of our model. According to the result, it is obvious that for independent variables, both coefficients of the dummy variable and quantity of employment have $p$ values significantly higher than 0.01 . Therefore, this study cannot reject the $\mathrm{H} 0$ assumption for these two estimates with a significance level of $1 \%$. In other words, the coefficients of $\mathrm{G}$ and $\mathrm{E}$ are not significantly different from 0 .

Table 1. Regression Result of the 1st Model

\begin{tabular}{ccc}
\hline Variable & Coefficient & P Value \\
\hline C & 5.139898 & 0.5940 \\
LOG $(T)$ & -0.260894 & 0.0005 \\
G & -0.017638 & 0.6793 \\
LOG(EC) & 2.282196 & 0.0000 \\
LOG(E) & -0.495249 & 0.3278 \\
\hline
\end{tabular}

Since the result of the model indicates the unreliability of estimates of two independent variables. One more multiple linear regression model is then performed without these two variables. Table 2 present the result of the adjusted regression model. It shows that two coefficients of two independent variables have a $\mathrm{p}$ value less than $1 \%$, indicating that the overall fitting effect of the model is significant. Therefore, the final regression equation would be:

$\operatorname{Ln} \mathrm{GDP}_{\mathrm{t}}=-4.4045-0.2174 \operatorname{Ln~}_{\mathrm{t}}+2.2296 \mathrm{Ln} \mathrm{E}_{\mathrm{t}}+\mathrm{e}_{\mathrm{t}}$
Table 2. Regression Result of the 2nd Model

\begin{tabular}{ccc}
\hline Variable & Coefficient & P Value \\
\hline C & -4.40452 & 0.0001 \\
LOG(T) & -0.21739 & 0.0001 \\
LOG(EC) & 2.229558 & 0.0000 \\
& Adjusted R-squared $=0.994073$ \\
\hline
\end{tabular}

\subsection{Result Analysis}

The result of the last model indicates the positive correlation between energy consumption and GDP while the negative correlation between tariff and GDP.

The final equation suggests higher average tariff contributes to the greater GDP of India. One percent increase in the tariff leads to a 0.2174 percent decrease in GDP. Reduction in trade barriers has been processed consistently since the 1970s. However, the high average tariff seems to act as a barrier to the development of the Indian economy currently. This result also indicates that when energy consumption increases by 1 percent, the GDP of India becomes 2.2296\% higher. An adjusted Rsquared value higher than $99 \%$ shows that change in independent variables can explain a 99\% change in GDP. Since our model reveals a weak relationship between whether India joins in regional trade agreement and GDP, this result can help answer the research question of why protectionism can still be essential for the Indian government.

\section{DISCUSSION}

Based on the literature review, it is obvious that previous scholars normally hold opposite attitudes toward protectionism, and most of them hold the point of view that protectionism has more disadvantages than advantages. Although the result indicates whether India joins in a regional trade agreement or not and GDP is irrelevant, it also presents that it can be beneficial for the Indian government to decrease the average tariff. This can be explained by the negative impacts of high trade barriers, including fewer business opportunities for domestic firms due to the increased cost of international supply chains, the lower incentive for domestic firms to increase efficiency due to uncompetitive markets, breed corruption, etc. Despite the result that lower tariffs would lead to higher GDP, this paper found it is vitally important for the Indian government to adopt protectionism to a certain extent for several significant advantages that help boost economic development. Based on the result and discussion of protectionism, this paper will also provide suggestions for the Indian government.

Trade protectionism would positively influence domestic industries in some respects, especially infant industries. Countries should gain a full understanding of the potential benefits of protectionism in order to make appropriate policies. And this paper suggests that protectionism mainly has two advantages. 
Firstly, protectionism can protect the development of the domestic industry by raising the domestic price of foreign commodities. Even though we have already mentioned that protectionism will negatively impact the domestic industry, the fundamental purpose of protectionism is to protect the domestic market and domestic enterprises. There is no doubt that protectionism will provide a relatively stable environment for domestic industries to grow, which is especially important for some industries when they are infants. Pugel, in 2014 showed that it cuts down on imports while the domestic infant industry learns how to produce at low enough costs [20]. At the same time, this is also important for industries facing many threats from foreign companies. When industries lack a competitive advantage, they would greatly influence the domestic economy.

The pharmaceutical industry serves as a classic example of protectionism. Medicine is relatively developed in India, but this was not the case before Gandhi's Government published The Patents Act, 1970. The government allowed Indian pharmaceutical enterprises to produce generics in a large quantity. India waived intellectual property protection for drugs. Besides, the government also imposed a higher tariff on imported medicines and posed restrictions on transnational drug companies. This series of measurements provided the pharmaceutical industry a well-protected environment to grow. As a result, the pharmaceutical industry experiences rapid development since 1970. Lofgren in 2004 showed that in 1970, domestic companies supplied only around 20 percent of the drug market; by the 1990s, this figure had increased to around 80 percent, and India had achieved self-sufficiency in the production of most basic medicines [21]. Figure 2 shows a considerable increase in the number of pharmaceutical companies from 1970 to 2000 .

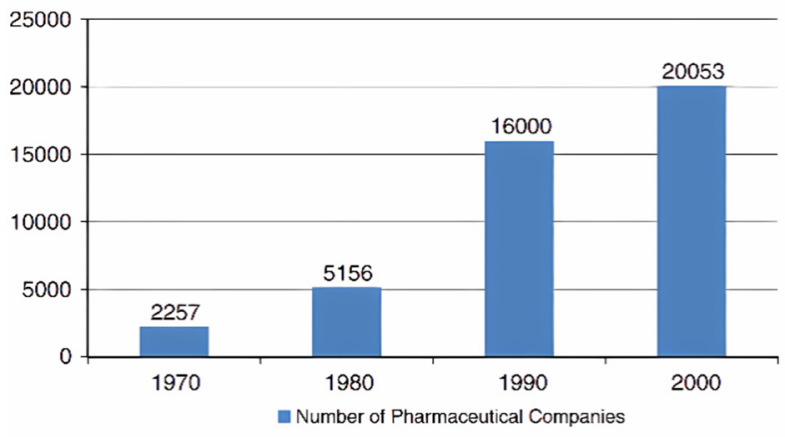

Figure 2. Growth of India's Pharmaceutical Industry [22]

However, things will change as WTO forces India to follow the rules of the TRIPS agreement. This means India may open its market again gradually when its pharmaceutical firms are asked to gain the patent of medicine. Lofgren in 2005 showed that open the market is not an easy step for India, but the Indian Patents Act has already been modified in the past decade to bring it closer to TRIPS [23]. This is mainly because this industry has become more and more mature, and therefore the government has the confidence to open the market to face these challenges. Figure 3 displays ever-increasing total and foreign sales of Indian generic drug companies, indicating a mature industry. However, without trade barriers, countries with insufficient discourse rights, like India, will face challenges, including becoming less competitive due to higher costs and not satisfying basic medical needs for poor people. Thus, protectionism still serves as one essential to guarantee the development of the Indian pharmaceutical industry.

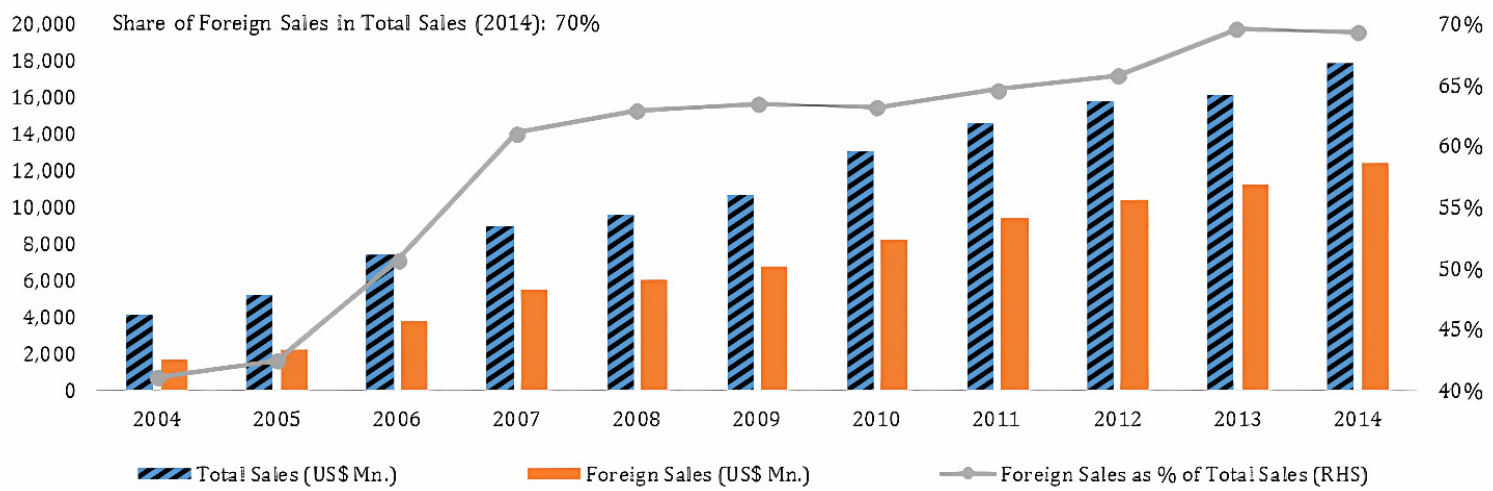

Figure 3. Sales Growth-Indian Generic Drug Companies [24]

Secondly, an increase in government revenue can contribute to more rapid development in several aspects. With a higher level of tariffs, protectionism would increase government revenue to a certain extent. Bakitoby and others in 2019 showed that low-income countries receive on average about 16 percent of their government revenue from customs duties [25]. Figure 4 illustrates that the customs revenue accounts for more than $15 \%$ of the total tax revenue of India before 2016 , indicating its critical role in the government revenue of India. 


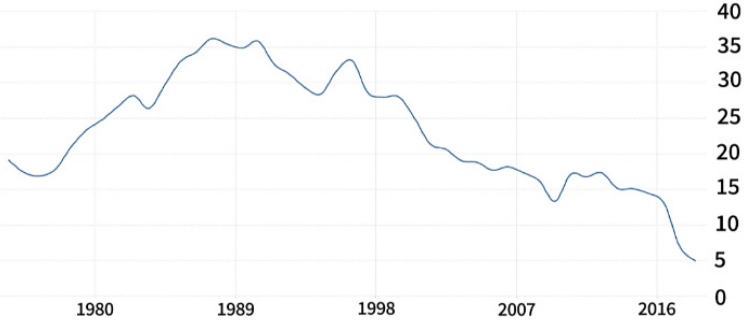

Figure 4. India-Customs and Other Import Duties (\% of Tax Revenue) [26]

The increasing government revenue could be used on army building to improve the quality of national defense security, cultural construction to enhance the living quality of people, infrastructure construction to improve people's living conditions. More importantly, the government could subsidize particular industries and help them develop at a dazzling speed. Tables 3 shows that the spending on major subsidies plays the second largest part of total central government expenditure, and these subsidies play an important role for many people from less developed backgrounds to survive. Therefore, tariff escalation would raise government revenue to a certain extent, resulting in stronger government support to develop domestic industries. And because of the importance of tariff in tax, the Indian government can keep a certain level of tariff to raise government income, which would enhance the development of domestic industries.

Tables 3. Central Government Expenditure of India for 2019-20 (in ₹ crore) [27]

\begin{tabular}{|c|c|c|c|}
\hline Heads & Amount & Heads & Shortcuts \\
\hline Pension & $1,74,300$ & Interest & $6,60,471$ \\
\hline Defense & $3,05,296$ & IT and Telecom & 21,783 \\
\hline $\begin{array}{l}\text { Major } \\
\text { Subsidies }\end{array}$ & $3,01,694$ & $\begin{array}{l}\text { Planning } \\
\text { Statistics }\end{array}$ & 5,814 \\
\hline $\begin{array}{l}\text { Agriculture } \\
\text { and Allied } \\
\text { Activities }\end{array}$ & $1,51,518$ & Rural Development & $1,40,762$ \\
\hline $\begin{array}{l}\text { Commerce \& } \\
\text { Industry }\end{array}$ & 27,043 & $\begin{array}{l}\text { Scientific } \\
\text { Departments }\end{array}$ & 27,431 \\
\hline $\begin{array}{l}\text { Development } \\
\text { of Northeast }\end{array}$ & 3,000 & Social Welfare & 50,850 \\
\hline Education & 94,854 & Tax Administration & $1,17,285$ \\
\hline Energy & 44,638 & Transfer to States & $1,55,447$ \\
\hline $\begin{array}{l}\text { External } \\
\text { Affairs }\end{array}$ & 17,885 & Transport & $1,57,437$ \\
\hline Finance & 20,121 & Union Territories & 15,098 \\
\hline Health & 64,999 & Urban Development & 48,032 \\
\hline \multirow[t]{2}{*}{ Home Affairs } & $1,03,927$ & Others & 76,665 \\
\hline & & Grand Total & $27,86,349$ \\
\hline
\end{tabular}

\section{CONCLUSION}

As globalization has been increasingly popular worldwide, this paper concentrates on how protectionism influences the Indian economy, one of the most representative economies of the developing countries, and whether protectionism is beneficial or harmful to India in various circumstances. In addition, this paper reviewed other scholars' opinions toward protectionism that most professions hold a negative view of using protectionism to protect domestic industries and enterprises. Through quantitative analysis, this paper indicates that lower average tariff contributes to the greater GDP of India, and this result presents the harmfulness of protectionism for the Indian economy to some extent. However, this paper further discusses the reason for high trade barriers in India using the pharmaceutical industry in India as a case. It indicated that adopting protectionism policies in India guarantees the development of the domestic industry, especially the infant industry, and suggests that the Indian government could place appropriately high barriers in specific industries to protect the development of domestic industries. To sum up, this paper makes a conscious effort to demonstrate the two sides' effect of protectionism. Although trade protectionism policies, including high tariff rates, can harm the GDP of developing countries like India, these measurements might be helpful for domestic firms to cope with challenges arising from the trend of globalization. Regarding the limitation, firstly, the regression model ignores the autoregressive and delay effect of tariff and whether India joins in a new RTA. Secondly, limited access to the data like quota is also one drawback of the model used in this research. Moreover, this paper discusses a limited number of industries, leading to the failure to demonstrate sufficient examples for further analysis. Therefore, further research, including analysis of more industries and models with lagged variables, can considerably help improve this research.

\section{REFERENCES}

[1] Mussa, Michael. "Meeting the challenges of globalisation." Journal of African economies 12.suppl_1 (2003): 14-34.

[2] Rodriguez, Francisco, and Dani Rodrik. "Trade Policy and Economic Growth: A Skeptic's Guide to the Cross-National Evidence." Nber Macroeconomics Annual 15.1 (2000): 261-338.

[3] Prachi Gupta, Matthias Helble. "Adjustment to trade opening: The case of labor share in India's manufacturing industry." The Journal of International Trade \& Economic Development (2021). DOI: 10.1080/09638199.2021.1949379

[4] India - Import TARIFFSINDIA - Import Tariffs." India - Import Tariffs | Privacy Shield 
[5] Abboushi, Suhail. "Trade protectionism: reasons and outcomes." Competitiveness Review: An International Business Journal (2010).

[6] Cambazoğlu, Birgül. "Trade Protectionism: Pros and Cons." International Trade Policies in the Era of Globalization. IGI Global, 2020. 94-115.

[7] Abboushi, Suhail. "Trade protectionism: reasons and outcomes." Competitiveness Review: An International Business Journal (2010).

[8] Baldwin, Robert E., and Richard K. Green. "The effects of protection on domestic output." Trade Policy Issues and Empirical Analysis (1988): 205231.

[9] Kaempfer, William and Willett, Thomas. Why an Import Surcharge Wouldn't Help America's Trade Deficit. The World Economy (1987). DOI:10.1111/j.1467-9701.1987.tb00080.x

[10] McGee, Robert W. "The philosophy of trade protectionism, its costs and its implications." Policy Analysis 10 (1996).

[11] Hickok, Susan. "The consumer cost of US trade restraints." Federal Reserve Bank of New York Quarterly Review 10.2 (1985): 1-12.

[12] McGee, Robert W. "The philosophy of trade protectionism, its costs and its implications." Policy Analysis 10 (1996).

[13] Baughman, Laura Megna, and Thomas Emrich. "Analysis of the impact of the Textile and Apparel Trade Enforcement Act of 1985." International Business and Economic Research Corporation, cited in Destler and Odell (1987).

[14] Luttrell, Clifton B. "Imports and Jobs-The Observed and the Unobserved." Review (1978).

[15] McGee, Robert W. "The philosophy of trade protectionism, its costs and its implications." Policy Analysis 10 (1996).

[16]“A Shield That's Not Required." YaleGlobal Online, 15 Jan. 2015. Gale In Context: Opposing Viewpoints, link.gale.com/apps/doc/A397606821/OVIC?u=col umbiau\&sid $=$ summon\&xid $=$ b696ae72. Accessed 6 July 2021.

[17] Census and Economic Information Center. https://www.ceicdata.com/en

[18] The World Bank. https://data.worldbank.org/country/india.

[19] Tariff Download Facility Database of WTO. http://tariffdata.wto.org/Default.aspx.
[20] Thomas A. Pugel, Peter H, and Lindert. International Economics. Chicago, Ill: Irwin, 2015. Print.

[21] Lofgren, Hans. "Patently Unfair Trade [India's State-Protected Pharmaceutical Industry Is Being Patented, Privatised and Plundered by WTO Trade Rules.].” 2005. Arena Magazine (Fitzroy, Vic), no. 77, Arena Printing and Publishing Pty Ltd, 2005, pp. $48-50$,

https://search.informit.org/doi/10.3316/ielapa.2005 08038 .

[22] Monteiro, Guilherme, Pianna, Anelise. "Institutional change and capability building: some remarks on the institution-based view of strategy. "Int. J. of Strategic Change Management. 4. 52 - 67. 10.1504/IJSCM.2012.045830.

[23] Malhotra, Prabodh, and Lofgren, Hans. "India's pharmaceutical industry: hype or high tech takeoff?." Australian health review 28.2 (2004): 182193.

[24] "India's Generic Drug Manufacturers: Poised for Continued Growth.” Nasdaq, www.nasdaq.com/articles/indias-generic-drugmanufacturers-poised-continued-growth-2016-0229.

[25] Akitoby, Bernardin, et al. "Tax revenue mobilization episodes in developing countries." Policy Design and Practice 3.1 (2020): 1-29.

[26] The World Bank. Customs and other import duties (\% of tax revenue) - India. https://data.worldbank.org/indicator/GC.TAX.IMP T.ZS?locations $=\mathrm{IN}$.

[27] Union Budget of India. Government of India, archive.pib.gov.in/archive2/docpagenew.aspx?doci $\mathrm{d}=650$. 